Article

\title{
Agro-Industrial Wastes: A Substrate for Multi-Enzymes Production by Cryphonectria parasitica
}

\author{
Salvatore Savino ${ }^{1}\left(\mathbb{D}\right.$, Daniela Bulgari ${ }^{2, *} \mathbb{C}$, Eugenio Monti ${ }^{1,+}$ and Emanuela Gobbi ${ }^{2,+}{ }^{+}$ \\ 1 Unit of Biotechnology, Department of Molecular and Translational Medicine (DMMT), University of Brescia, \\ viale Europa 11, 25123 Brescia, Italy; s.savino@unibs.it (S.S.); eugenio.monti@unibs.it (E.M.) \\ 2 Agri-Food and Environmental Microbiology Platform (PiMiAA), Department of Molecular and \\ Translational Medicine, University of Brescia, viale Europa 11, 25123 Brescia, Italy; emanuela.gobbi@unibs.it \\ * Correspondence: daniela.bulgari@unibs.it \\ + These authors equally contributed to the work.
}

Citation: Savino, S.; Bulgari, D.;

Monti, E.; Gobbi, E. Agro-Industrial

Wastes: A Substrate for

Multi-Enzymes Production by

Cryphonectria parasitica. Fermentation

2021, 7, 279. https://doi.org/

$10.3390 /$ fermentation7040279

Academic Editor:

Łukasz Łopusiewicz

Received: 22 October 2021

Accepted: 23 November 2021

Published: 26 November 2021

Publisher's Note: MDPI stays neutral with regard to jurisdictional claims in published maps and institutional affiliations.

Copyright: (c) 2021 by the authors. Licensee MDPI, Basel, Switzerland. This article is an open access article distributed under the terms and conditions of the Creative Commons Attribution (CC BY) license (https:/ / creativecommons.org/licenses/by/ $4.0 /)$.

\begin{abstract}
This study aims to produce a mix of enzymes through Solid State Fermentation (SSF) of raw materials. Four different, easily available, agro-industrial wastes were evaluated as SSF substrates for enzymes production by Cryphonectria parasitica (Murr.) Barr. environmental strains named $\mathrm{CpA}, \mathrm{CpB2}, \mathrm{CpC} 4$, and $\mathrm{CpC7}$. Among the tested wastes, organic wheat bran for human use and wheat bran for animal feed better supports $C$. parasitica growth and protease production without any supplements. SDS-PAGE analyses highlighted the presence of three bands corresponding to an extracellular laccase $(77 \mathrm{kDa})$, to the endothiapepsin $(37 \mathrm{kDa})$, and to a carboxylesterase $(60.6 \mathrm{kDa})$. Protease, laccase, and esterase activities by C. parasitica in SSF were evaluated for 15 days, showing the maximum protease activity at day 9 (3955.6 AU/gsf,). Conversely, the best laccase and esterase production was achieved after 15 days. The C. parasitica hypovirulent $\mathrm{CpC} 4$ strain showed the highest laccase and esterase activity (93.8 AU/gsf and $2.5 \mathrm{U} / \mathrm{gsf}$, respectively). These results suggest the feasibility of a large-scale production of industrially relevant enzymes by C. parasitica strains in SSF process on low value materials.
\end{abstract}

Keywords: esterase; aspartic protease; laccase; solid state fermentation; wheat bran; by-products

\section{Introduction}

Currently, a key theme in sustainable development is the requirement of appropriate waste management (UNEP, 2011; UNHSP, 2010), based on the notion that waste can be a resource [1,2]. Agriculture and food processing produce solid organic wastes in large quantities and their improper disposal may cause severe environmental, social, and economic impacts. Agro-food wastes and by-products have been receiving growing attention as they are abundant [3], and rich in proteins, sugars and minerals which can be converted and assimilated by microorganisms [4]. One attractive valorization of agro-food wastes is their application in bio-refinery processes as substrates for microbial growth to produce various commodity chemicals and industrial enzymes [5-7].

The industrial importance of enzymes as biological catalysts ranges from the food industry to paper, pulp, and detergent treatments. Currently, 60\% of the global market is covered by proteases, with applications in detergents, leather processing, food and feed processing, pharmaceuticals, chemicals, and waste treatment [8]. Among the remaining enzymes, laccases are polyphenol oxidases involved in biopulping and bioleaching, denim washing, textile dye decolorization, and wastewater treatment $[9,10]$ and esterases and lipases are used in many industrial applications, such as for detergents [11,12]. Enzymes are relatively expensive reagents: around $30-40 \%$ of their production cost is accounted for by the fermentation substrate that could be greatly reduced by using low-cost substrates such as agro-food residues [13]. 
Microorganisms, fungi in particular, have been regarded as a treasure source of useful enzymes for the positive environmental impact of their production processes. In fact, fungi can grow on low-cost materials while secreting high amounts of enzymes, which eases downstream processing [14]. In addition, fungal enzymatic production is not subjected to ethical evaluation and consequent regulatory issues, as long as its use is confined to specific fermentation facilities and proper disposal is implemented.

A relevant part of the world enzyme market derives from microorganisms under submerged fermentations (SmF) [15] due to high amounts of enzyme recovered, lowcost production, and, finally, stability of the polypeptides at various extreme conditions. However, over the last twenty years, the interest in solid state fermentation (SSF) processes have markedly increased, appearing in a large number of patents and publications [16]. SSF is a promising technology enabling microorganisms to produce biomolecules by growing on solid substrates used both as a physical support and as a source of nutrients in an environment with the absence or near absence of free-flowing liquid $[13,17]$.

SSF has some advantages over SmF, since the provided environmental conditions resembles the natural habitat of the fungus [18], allowing adequate growth and high yield of target enzymes production. Furthermore, SSF has a lower energy requirement and demands simpler extraction processes to obtain the desired enzymes [4,19-21].

Therefore, there is an increasing interest in the bioprocessing of agro-industrial wastes through SSF, achieving their valorization to produce industrial enzymes [22-24]. In most cases, filamentous fungi are particularly interesting for SSF processes, since they have the unique capacities to colonize the interparticle spaces of solid matrices and to secrete mixtures of enzymes, in place of single enzymes, that allow to metabolize complex mixtures of organic compounds found in most residues, as required by several industries [25-27]. Unfortunately, few fungal strains meet the criteria for commercial production, so far. In fact, the production of low-cost and readily available enzymes possessing suitable operating characteristics is still challenging.

Cryphonectria parasitica (Murr.) Barr is a filamentous ascomycete well known for its ability to secrete a range of proteins with industrial applications that are being commercially produced through different fermentation procedures [28-31]. For example, milk-clotting enzymes were produced by C. parasitica, and they are considered as GRAS (generally recognized as safe) substances [32].

Interestingly, C. parasitica is also the agent of the plant disease chestnut blight, causing relevant economic losses worldwide [33]. C. parasitica is also a model study for mycovirusfungi interactions, since it naturally harbors a number of viruses, among which is Cryphonectria hypovirus-1 (CHV1), a mycovirus that alters the host virulence and is used for natural biocontrol [34]. CHV1 is also known to down- and up-regulate the expression of several genes, with a corresponding reduction/increase of the relative products including enzymes [35,36].

The present study aims at the definition of an eco-friendly multiple enzymes production protocol through SSF. More precisely, the feasibility of different food wastes as sole substrates, with no supplements, has been evaluated for the growth and the production of aspartic endopeptidase (EC 3.4.23), carboxylesterase, and laccase (EC 1.10.3.2) by environmental C. parasitica strains under SSF.

\section{Materials and Methods}

\subsection{Microorganisms and Their Molecular Characterization}

Four Cryphonectria parasitica strains, named CpA, CpB2, CpC4, and CpC7 (Table 1), newly isolated from cankers on a Castanea sativa Mill in two Italian regions, were morphologically identified and stored in the collection of the Agri-food and Environmental Microbiology Platform (PiMiAA), University of Brescia, Italy. The strains were maintained as agar plugs of mycelium in sterile distilled water at $4{ }^{\circ} \mathrm{C}$. The cultures were grown on Potato Dextrose Agar (PDA, Merck, Milano, Italy), and incubated for 6 days at $26^{\circ} \mathrm{C}$ under the illumination of $16 \mathrm{~h}$ light/ $8 \mathrm{~h}$ dark cycles, using daylight tubes $24 \mathrm{~W} / \mathrm{m}^{2}, 9000 \mathrm{~lx}$. 
Fungal inocula were prepared as mycelial slurry by grinding a fully-grown culture plate (diameter $9 \mathrm{~cm}$ ) in a Waring blender, with the addition of $26 \mathrm{~mL}$ of sterile deionized water.

Table 1. Environmental strains of Cryphonectria parasitica used in this study. The presence of the hypovirus CHV1 is indicated by + .

\begin{tabular}{cccc}
\hline Strain & Origin & Canker Type & CHV1 \\
\hline $\mathrm{CpA}$ & Tuscany & evolutive & - \\
$\mathrm{CpB} 2$ & Tuscany & evolutive & - \\
$\mathrm{CpC} 4$ & Lombardy & superficial & + \\
$\mathrm{CpC7}$ & Lombardy & evolutive & - \\
\hline
\end{tabular}

To assess the presence of Cryphonectria hypovirus-1 (CHV1), the C. parasitica strains were grown on PDA covered with a sterile cellophane disc, inoculated with mycelial plugs, and incubated at $26^{\circ} \mathrm{C}$ for four days [37]. Mycelium was harvested by scraping with a sterile scalpel, lyophilized, and the RNA was extracted using the PureLink RNA purification kit (Ambion, Thermo Scientific, Milano, Italy). Synthesis of cDNA from RNA was performed using a cDNA first strand synthesis kit (Thermo Fisher, Milano, Italy) with hexamer primer, according to the manufacturer's instruction.

CHV1 was detected by qRT-PCR using cDNA, prepared as described above, as a template. Reactions were performed using the Real-time PCR PowerUp SYBR Green Master Mix kit (Applied Biosystem, Milano, Italy) in the ViiA7 Real-time PCR system (Applied Biosystems, Milano, Italy) and by adopting the specific primers (5337) ACCTGGTTCGCCGAAGAAC Rev (5405) GCAACCTCTAAGGCAACCA [38].

\subsection{Agro-Food Waste Based Substrates and Solid State Fermentation}

2.2.1. Effect of the Carbon Source on the Fungal Growth and Protease Activity

Wheat bran for human (organic wheat bran, $\mathrm{OW}$ ) or for animal consumption (zootechnical wheat bran, $\mathrm{ZW}$ ), and rice husk (RH), all bought at local stores, and spent espresso coffee grounds (CG) collected from bars after espresso preparation in Brescia, Italy, were the by-products used as substrates for fungal growth and enzymes production (Table 2). SSF was carried out in $340 \mathrm{~mL}$ micropropagation boxes equipped with a $0.45 \mu \mathrm{m}$ filter (Micropoli, Cesano Boscone, Italy) containing $11 \mathrm{~g}$ of each waste. The dry substrates in boxes were autoclaved twice at $121{ }^{\circ} \mathrm{C}$ for $20 \mathrm{~min}$.

Table 2. Approximate chemical composition ( $\mathrm{g} / 100 \mathrm{~g}$ dry material) retrieved from scientific literature of feed stocks used in this study.

\begin{tabular}{cccc}
\hline & \multicolumn{3}{c}{ Substrate for SSF } \\
\cline { 2 - 4 } Chemical & Wheat Bran $(\mathbf{Z W}$ *) & Rice Husk (RH) & $\begin{array}{c}\text { Spent Coffee } \\
\text { Grounds (CG) }\end{array}$ \\
\hline Components & 32 & 33.4 & 12.5 \\
Cellulose & 21 & 21 & 39 \\
Hemicellulose & 22 & 18.3 & 24 \\
Lignin & 26.6 & 1.1 & 30 \\
Carbohydrates & 14.1 & 2 & 17.5 \\
Protein & 5.5 & 0.8 & 2.3 \\
Lipids & 0.5 & 15.5 & 1.3 \\
Ash & & & \\
\hline
\end{tabular}

* Similar to OZ.

\subsubsection{Effect of Water Content on the Fungal Growth and Protease Activity}

Different moisture contents were tested depending on the substrate composition. The optimum water content of the dried substrates was studied over a range of 1:1 (wet basis) (OWA, ZW, RH, and CGA); 1.5:1 (OWB) and 2:1 (CGB). Different moisture contents were adjusted with deionized water. 


\subsubsection{Effect of Substrate Density on the Fungal Growth and Protease Activity}

To analyze the effect of the substrate density, the activity was tested at different porosity using rice husk. RH substrate was separated into two series, one was milled with a Waring blender (RHM), and the other series was unmilled (RHU).

\subsection{SSF Protocol Set Up}

Fungal inocula were prepared as mycelial slurry by grinding a fully-grown culture plate (diameter $9 \mathrm{~cm}$ ) in a Waring blender, with the addition of $26 \mathrm{~mL}$ of sterile deionized water.

Each substrate was inoculated with $2 \mathrm{~mL}$ of the mycelium slurry, and incubated for 15 days at $24^{\circ} \mathrm{C}$, with a photoperiod of $16 \mathrm{~h}$, and $50 \%$ relative humidity in a climatic chamber (Binder Model 720, Milano, Italy). Samples (approximately 1-2 g) were aseptically withdrawn at various time intervals $(6,9,12$, and 15 days) for the determination of carboxylesterase, aspartic endopeptidase, and laccase activity, or frozen at $-20{ }^{\circ} \mathrm{C}$ until analyses. Five replicates for each substrate were prepared, and the experiment was repeated twice. The fungal growth was visually quantified by assigning a score based on the timing of appearance and the abundance of both substrate colonization and pycnidia production, with a scale from very poor $(-/+)$ to abundant $(++)$ growth.

\subsection{Extraction of Crude Enzyme from the Fermented Media}

Liquid-solid enzymes extraction was performed from solid fermented substrates with distilled water $(1: 10, w / v)$ by shaking at $170 \mathrm{rpm}$ for $2 \mathrm{~h}$ at room temperature, followed by centrifugation of the whole content at $5000 \times \mathrm{g}$ for $15 \mathrm{~min}$ at $4{ }^{\circ} \mathrm{C}$. The supernatants were used as crude enzyme source.

\subsection{Protease Activity Assay}

The proteolytic activity was measured by a modification of the hemoglobin method [39]. In short, $20 \mu \mathrm{L}$ of diluted enzyme solution were added to $500 \mu \mathrm{L}$ of pre-warmed bovine serum hemoglobin (Merck, Milano, Italy) solution, mixed, and incubated at $37{ }^{\circ} \mathrm{C}$ for $15 \mathrm{~min}$. The reaction was stopped by adding trichloroacetic acid (TCA), and the mixture was cooled on ice and centrifuged at $20,000 \mathrm{~g}$ for $10 \mathrm{~min}$ at $4{ }^{\circ} \mathrm{C}$ to remove the unhydrolyzed protein. The absorbance of the clear supernatant solution was measured at Abs $280 \mathrm{~nm}$; the blanks were prepared by using the same amount of assay solution, and reversing the order of addition of TCA and hemoglobin solutions. The protease activity is expressed as Abs $280 \mathrm{~nm}$ in arbitrary units (AU). One AU is defined as the enzyme amount that produces an increase of Abs $280 \mathrm{~nm}$ of 0.01 under the assay conditions [40,41], measured as the quantity of TCA-soluble products [42]. The observed AU values are normalized by gram of fermented substrate $\left(\mathrm{AU} / \mathrm{g}_{\mathrm{sf}}\right)$.

\subsection{TBA Assay}

As a preliminary screening for lipolytic activity of crude extracts, the modified TriButyrin Agar Plate Assay [43] was carried out on TBA medium containing 1\% tributyrin $(v / v)$ and $1.5 \%$ agar $(w / v)$ in $10 \mathrm{~cm}$ diameter plates. Aliquots $(20 \mu \mathrm{L})$ of the crude enzyme extractions were placed in wells in the agar. All plates were incubated at $25{ }^{\circ} \mathrm{C}$ overnight, and lipolytic hydrolysis was verified as presence of clear zone around the wells.

\subsection{Esterase Activity Assay}

The esterase activity was determined spectrophotometrically by measuring the hydrolysis of 4-nitrophenyl butyrate (pNPB) (Sigma, Milano, Italy) as a substrate [44]. The pNPB dissolved in acetonitrile $(50 \mathrm{mM})$ was added to $200 \mu \mathrm{L}$ Na phosphate buffer $(100 \mathrm{mM}$, $\mathrm{pH} 7.5$ ) with $0.5 \%$ Triton X-100 (v/v) (Sigma, Milano, Italy), to $0.5 \mathrm{mM} \mathrm{pNPB}$ as a final concentration; $10 \mu \mathrm{L}$ crude enzyme extraction were used as enzyme source. The enzymatic reaction was carried out at $25^{\circ} \mathrm{C}$ for $15 \mathrm{~min}$. The release of 4-nitrophenol (pNP) at $405 \mathrm{~nm}$ was measured by using a UV-VIS micro-plate reader (EnSight multimode reader, Perkin- 
Elmer Waltham, MA, USA). Enzyme activity calculated using the extinction coefficient of pNP corresponding to $18.5 \mathrm{mM}^{-1} \cdot \mathrm{cm}^{-1}$, One $\mathrm{U}(\mu \mathrm{mol} / \mathrm{min})$ is defined as the amount of the enzyme that catalyzes the conversion of one micromole of substrate per minute under the specified conditions of the assay method, and normalized by gram of fermented substrate $\left(\mathrm{U} / \mathrm{g}_{\mathrm{sf}}\right)$.

\subsection{Laccase Activity Assay}

The laccase activity was determined with 2,6-dimethyoxyphenol (DMP) (Carlo Erba, Milano, Italy) as a substrate [45]. The oxidation of DMP was spectrophotometrically determined by continuously recording the increase in absorbance at $468 \mathrm{~nm}$ at $25{ }^{\circ} \mathrm{C}$ for $15 \mathrm{~min}$ in a micro-plate reader (EnSight multimode reader, Perkin-Elmer Waltham, MA, USA). One arbitrary unit (AU) is defined as an increase Abs $468 \mathrm{~nm}$ of 1.0 per min at $25^{\circ} \mathrm{C}[46]$.

\subsection{SDS-PAGE}

SDS-PAGE of the crude extracts was performed using a $12 \%(w / v)$ running gel, (Laemmli, 1970). Protein bands were visualized by Coomassie Brilliant Blue staining, and their size estimated with the aid of the Protein Marker VI (molecular weight range from 10 to $245 \mathrm{kDa})$.

\subsection{Protein Determination}

Protein concentrations were determined by Coomassie Protein Assay Reagent (Sigma, Milano, Italy), according to the method of Bradford [47], using bovine serum albumin (Sigma, Milano, Italy) as the standard.

\subsection{Statistical Analysis}

For all the experiments described in the manuscript, at least three biological replicates were performed, and the mean enzymes activities were statistically analyzed by analysis two-way analysis of variance (ANOVA) followed by Tukey's means grouping tests using GraphPad Prism software 6 for Windows (GraphPad Software, San Diego, CA, USA). Differences were considered significant at $p$-values $<0.05$.

\section{Results and Discussion}

Cryphonectria (formerly Endothia) parasitica is a well-known producer of a rennin-like protease and endothiapepsin [48], mainly used in the food industry, thanks to the GRAS status of the fungus derived additives [32]. In addition, C. parasitica has also been shown to produce and secrete a number of hydrolytic enzymes, including laccase [31], cellulase [28], polygalacturonase [49], cutinase [29], and tannase [30]. All of these enzymes are normally produced in liquid cultures, in fact, to the best of our knowledge; C. parasitica has never been cultivated in SSF regime so far. Consequently, the feasibility of using agro-food wastes as sole substrate for the growth and multiple enzymes production by C. parasitica in SSF needed to be explored.

Agro-food wastes are defined as lignocellulosic biomass, with lignin and celluloses as the main constituents. It is well known that the different materials used as substrate can modify the fungal gene expression and, consequently, the type and quantity of the produced enzymes, thus affecting their application in the biotechnological industry in many ways [50,51]. In the literature, the raw materials used as SSF substrates in this study are reported as characterized by the compositions shown in Table 2 [52-56]; as such they could support the growth of fungi and their enzymes production under SSF.

\subsection{SSF Protocol Set Up}

\subsubsection{Fungal Growth on Different Raw Material}

The growth of the strain $\mathrm{CpC7}$ on $\mathrm{OW}, \mathrm{ZW}, \mathrm{RH}$ and $\mathrm{CG}$ as solid substrate during a period of 15 days is summarized in Table 3. 
Table 3. Growth of the CpC7 strain on the different substrates used in this study. (a) "-" unmilled; "+" milled; (b) "-/+" very poor growth; "+" normal growth; "++" abundant growth.

\begin{tabular}{ccccc}
\hline Agro-Food Waste & Abbreviation & $\begin{array}{c}\text { Ratio } \\
\text { Water/Waste }\end{array}$ & Milled $^{\mathbf{a}}$ & $\begin{array}{c}\text { C. parasitica } \\
\text { Growth }^{\mathbf{b}}\end{array}$ \\
\hline \multirow{2}{*}{ Organic wheat bran } & OWA & $1: 1$ & - & ++ \\
Zootechnical wheat bran & OWB & $1.5: 1$ & - & ++ \\
Rice husk & ZW & $1: 1$ & - & ++ \\
\multirow{2}{*}{ Spent coffee grounds } & RHM & $1: 1$ & + & + \\
& RHU & $1: 1$ & - & $-/+$ \\
& CGA & $2: 1$ & - & $-/+$ \\
\hline
\end{tabular}

The best growth was achieved on all the wheat bran substrates, OWA, OWB and ZW; representative samples on OWA at different times of incubation are shown in Figure 1.
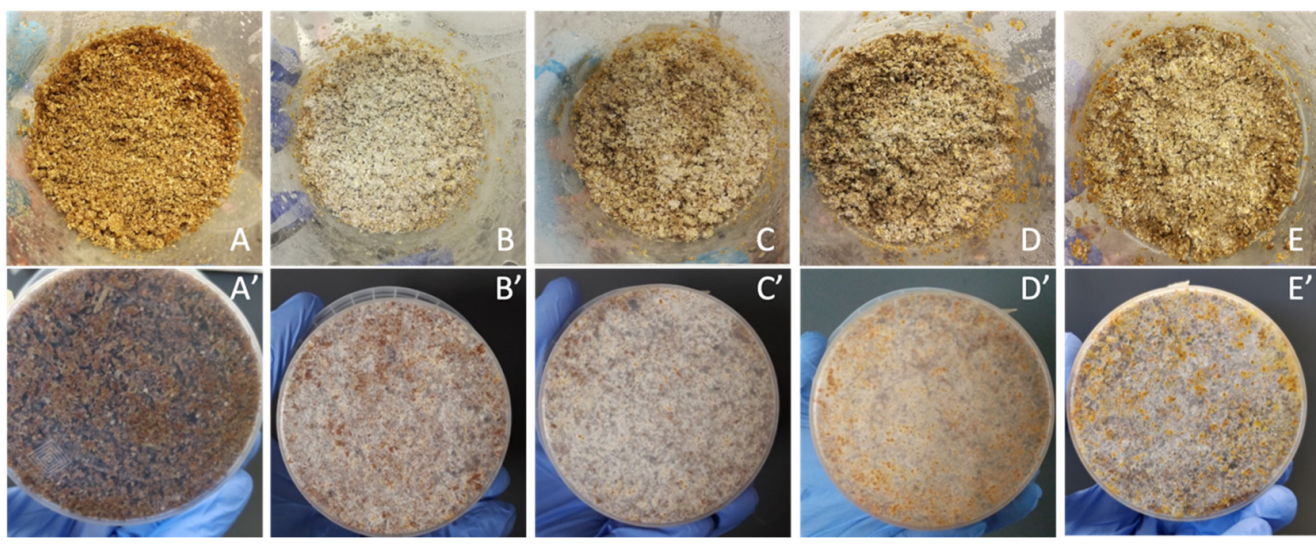

Figure 1. Growth of $\mathrm{CpC7}$ strain under SSF using organic wheat bran as solid substrate, at (B) 6 , (C) 9, (D) 12 and (E) 15 days of fermentation. The top (A-E) and bottom ( $\left.\mathbf{A}^{\prime}-\mathbf{E}^{\prime}\right)$ surfaces of the OWA colonized substrates are shown. $\left(\mathbf{A}, \mathbf{A}^{\prime}\right)$, not inoculated substrate.

In detail, fungal white mycelium was visible at day 4 after inoculation on the upper surface. It completely colonized the biomass at day 6 of incubation, with abundant orange pycnidia production visible at day 12 (Figure 1D'). As far as the effect of the water content is concerned, the fungal growth appeared earlier, and fructification was more abundant on OWB than on OWA, indicating that both water conditions were conducive to growth, but the higher water content of OWB was more supportive (data not shown).

Conversely, RH and CG resulted less conducive of fungal growth. In detail, the substrate density represented another decisive factor for the rate and extent of the biomass colonization and should be cautiously altered, as it resulted strictly associated to aeration of the biomass and eventually to its colonization. A very high density of the matrix elements occurred in CGA and CGB, where the small particles appeared to pack together tightly, and corresponded to a very poor fungal growth, limited only to the biomass surface (Figure S1). This behavior could be determined by the scarce oxygenation of the media that limited an extensive fungal growth [57].

Inversely, when the very coarse matrix RHU was compared to the more regular RHM (Figure S1), the latter allowed a better fungal growth with a faster colonization than RHU. In fact, the mycelium covered the substrate at day 7 with a good production of pycnidia, but nonetheless with a lower performance than on wheat bran. The coarse RHU turned out as the less appropriate substrate for C. parasitica growth.

No growth was observed on not inoculated substrates. 


\subsubsection{Protease Production under SSF}

The fungal enzymatic production was analyzed in the crude extract obtained from SSF at different time points. No aspartic protease activity was detected in CGA, CGB and RHB. Higher aspartic protease activity was found when $\mathrm{CpC7}$ grew on $\mathrm{OW}$ and $\mathrm{ZW}$ than on the other substrates, possibly due to the better fungal growth achieved on these wastes. On wheat bran substrates, aspartic protease activity was measured starting from day 4 of fermentation, with values above $2000 \mathrm{AU} / \mathrm{g}_{\mathrm{sf}}$. Protease production was not significantly influenced by wheat bran substrates composition. The maximum enzymatic activity was detected on day 8 , with values of $3980.6 \pm 646 \mathrm{AU} / \mathrm{g}_{\text {sf }}, 4123.5 \pm 1259.9 \mathrm{AU} / \mathrm{g}_{\text {sf }}$ and $3703.2 \pm 350.7 \mathrm{AU} / \mathrm{g}_{\text {sf }}$, for OWA, OWB, and ZW, respectively (Figure 2). Inversely, the protease activity was $133.6 \pm 32,7 \mathrm{AU} / \mathrm{g}_{\text {sf }}$ after 7 days of growth on RHA that was significantly lower $(95.0 \%$ of confidence interval, $p<0.05)$. After this peak, protease activity decreased to $20 \%$ of the correspond peak values.

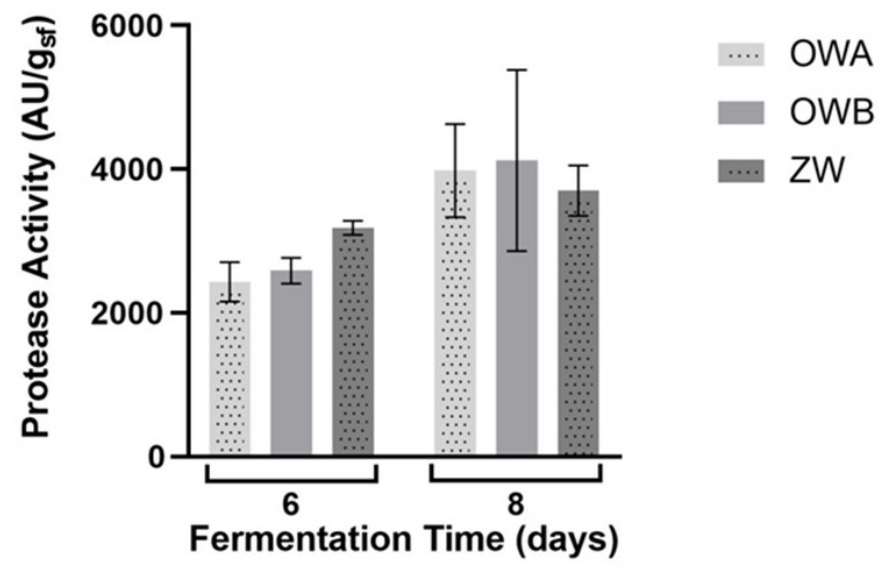

Figure 2. Effect of different wheat bran substrates (OWA, OWB and ZW) on protease production by $\mathrm{CpC7}$ strains under SSF conditions, after eight days of fermentation. Data represent the average \pm standard deviation of biological replicate cultures $(n=3)$.

In summary, wheat bran resulted to be conducive to fungal growth and to aspartic protease production without further supplementation. Moreover, wheat bran is a local waste for Italy, readily available in many regions, and hence a low-cost substrate.

As far as the water content of the substrate is concerned, the ratio water/waste 1:1 proved to be sufficient to ensure a very good growth and enzymatic production, making the process more affordable and sustainable, being far less water consuming in comparison to other reported methods for enzymes production either in SSF and SmF [40,57-61]. The potential presence of pesticide residues in the ZW, below the commercial threshold, but still able to interfere with the fungal growth, did not occur. Thus, even if the organic wheat bran OW gave a faster colonization, ZW was the economical choice as the sole substrate for further experiments of multiple enzymes production through SSF.

\subsubsection{Enzymes Putatively Identification}

Electrophoretic analysis of the crude enzymatic extracted at different time points of the CpC7 culture showed three main bands (Figure 3). These potentially corresponded to an extracellular laccase that migrates as a polypeptide with a molecular mass of approximately $77 \mathrm{kDa}$ [46] to the endothiapepsin of $37 \mathrm{kDa}$ (Brown et al., 1990), and to an unidentified protein of $27 \mathrm{kDa}$ (Figure 3). Moreover, a band potentially corresponding to a carboxylesterase of $60.6 \mathrm{kDa}$ [63] was present. This result suggests a good enzyme production and a purity of the crude extracts that might not require further purification steps. 


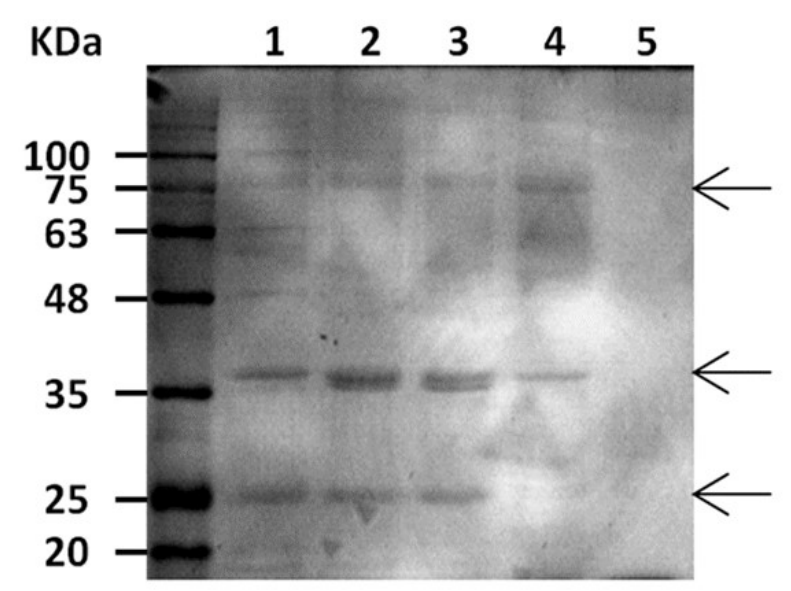

Figure 3. SDS-PAGE separation of enzyme crude extract produced at 4 (lane 1), 6 (lane 2), 8 (line 3), and 12 (line 4) SSF days by CpC7 on ZW; negative control (line 5). Arrows point to three main bands, respectively at 77, 37 and $27 \mathrm{KDa}$, putatively corresponding to extracellular laccase, endothiapepsin, and to an uncharacterized peptide.

\subsection{Multi-Enzymes Production under SSF}

Successively, the SSF protocol previously established was applied to grow four environmental strains of $C$. parasitica for the simultaneous multiple production of enzymes.

\subsubsection{Strains Characterization}

C. parasitica is a well-known fungus among plant pathologist as the agent of a severe disease of chestnut trees, where it normally produces perennial necrotic lesions, the socalled cankers. Some strains, however, are associated with superficial or healing cankers on susceptible host trees; these hypovirulent strains usually host a mycovirus, the RNA hypovirus CHV1, that decreases their ability to produce the disease on chestnut trees $[64,65]$ by affecting the expression of several genes.

Therefore, the environmental C. parasitica strains used in this work, isolated from cankers on chestnut trees, were characterized for the presence of CHV1, since it could influence their enzymatic production $[36,51,66]$. The RT-qPCR revealed the presence of CHV1 only in the CpC4 strain (Table 1).

\subsubsection{Multiple Enzymes Activities}

To the best of our knowledge, the concomitant production of protease, esterase, and laccase, by environmental C. parasitica strains under SSF on ZW was here reported for the first time.

The highest protease activity was registered at day 9 of fermentation, with comparable values among the 4 strains, ranging from $3955.6 \pm 279.1 \mathrm{AU} / \mathrm{g}_{\mathrm{sf}}$ for $\mathrm{CpA}$, to $3785.8 \pm 263.3 \mathrm{AU} / \mathrm{g}_{\mathrm{sf}}$ for CpB2 (Figure $4 \mathrm{~A}$ ) in spite of the similar total protein content of the different crude extracts of the isolates (Table S1).

The time course of the protease production was quite similar among all strains. In detail, the protease production increased from the sixth day up to the ninth, when it reached its maximum; a subsequent decrease of activity was observed with a plateau of production from day 12 in $\mathrm{CpB} 2$ and $\mathrm{CpC} 7$, or a more or less sharp decline in $\mathrm{CpC} 4$ and $\mathrm{CpA}$, respectively (Figure $4 \mathrm{~A}$ ). In general, this growth-associated protease production profile was already observed for other fungi $[59,67]$, and it is related to the degradation of extracellular enzymes and/or the depletion of available nutrients. 


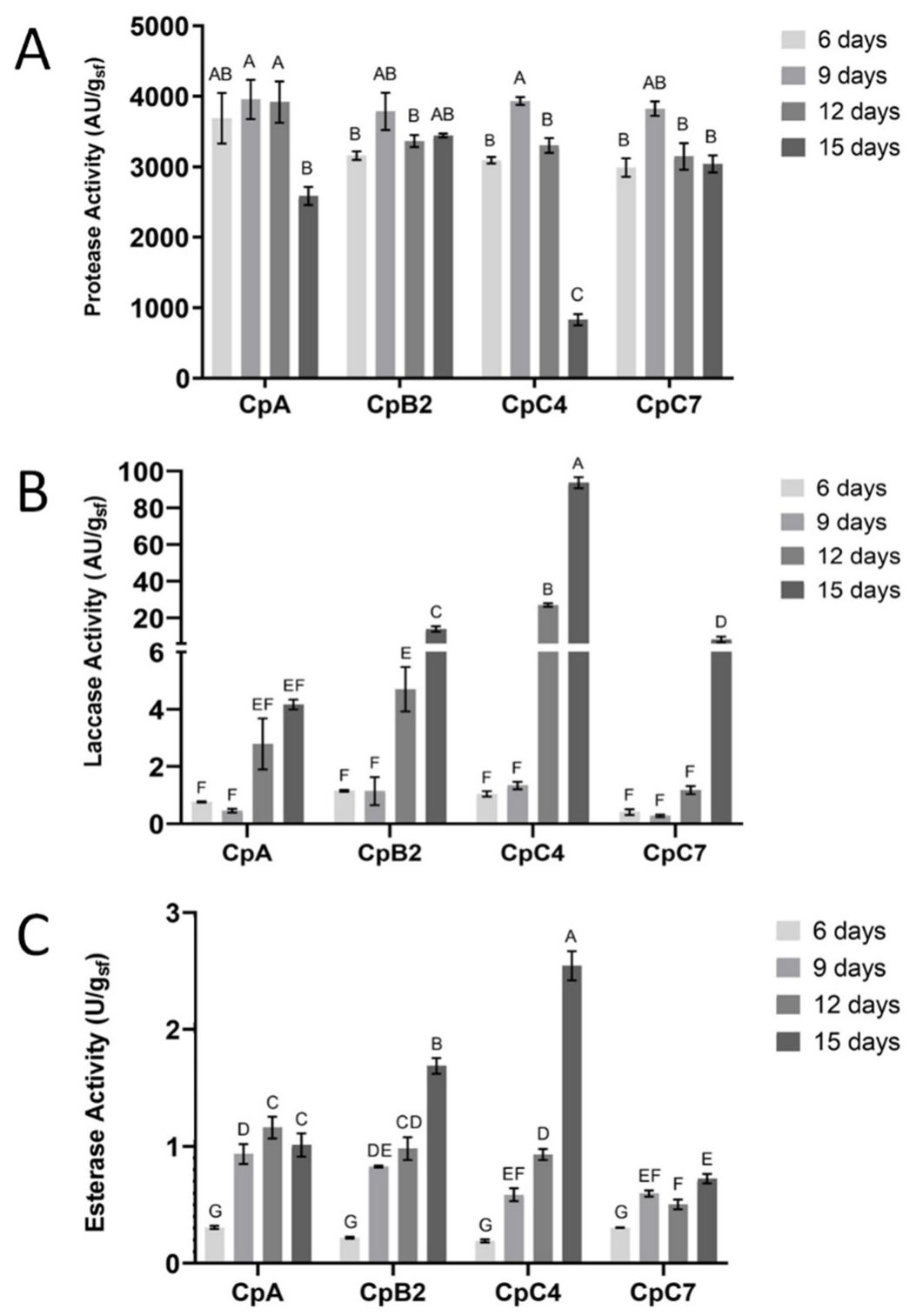

Figure 4. Time courses of protease (A), laccase $(\mathbf{B})$ and esterase activities $(\mathbf{C})$ produced by four C. parasitica environmental strains ( $\mathrm{CpA}, \mathrm{CpB} 2, \mathrm{CpC} 4, \mathrm{CpC})$, grown on $\mathrm{ZW}$ for 15 days. Different letters indicate significant differences $(p<0.05)$; means sharing a letter are not significantly different $(p>0.05)$. Data represent the average \pm standard deviation of biological replicate cultures $(n=3)$.

The same amount of protease was obtained by the virulent strains, as well as by the hypovirulent $\mathrm{CpC} 4$. As reported previously for the C. parasitica virus-free strain EP155 and its hypovirus infected isogenic strain, no significant changes upon hypovirus infection were detected in the production of extracellular enzymes taking part in nutrient utilization [63], such as the endothiapepsin precursor.

As far as laccase is concerned, its production occurred later in the fungal growth cycle, with a significant increase of the activity starting at day 12 in all the strains (Figure 4B). In detail, $\mathrm{CpC7}$ was characterized by a sharp increase reaching the maximum production at day 15 of growth. CpC4 strain proved to be the best producer, with a laccase yield of $93.8 \pm 2.9 \mathrm{AU} / \mathrm{g}_{\text {sf }}$ at day 15 of growth, significantly higher than the other strains, corresponding to 6.5-fold increase. No activity was observed on non-inoculated samples.

While both protease and laccase production by $C$. parasitica in various types of liquid culture has already been reported, esterase and lipase activities have been scarcely studied in this fungus. 
Preliminary evaluation of lipolytic activity by TBA assay evidenced a transparent halo around the disks with fungal crude extracts. These halos increased with the age of the cultures; notably, they appeared in the samples corresponding to day 9 and remained constant up to day 15. (Figure S2).

Here, for the first time, esterase activity was quantified in the crude extracts produced by environmental strains of $C$. parasitica. Esterase activity was significantly affected by the fermentation time following two different trends. In $\mathrm{CpB} 2$ and $\mathrm{CpC} 4$, the maximum esterase activity was reached after 15-day incubation with the yield of $1.69 \pm 0.07$ and $2.55 \pm 0.12 \mathrm{U} / \mathrm{g}_{\mathrm{sf}}$, respectively. In detail, the enzyme activity in $\mathrm{CpC} 4$, the best esterase producer, was 2.73 -fold higher at 15 days than at 12 days of incubation $\left(0.93 \pm 0.48 \mathrm{U} / \mathrm{g}_{\mathrm{sf}}\right)$. Inversely, $\mathrm{CpA}$ and $\mathrm{CpC7}$ esterase activity slightly increased to their maximum value of $1.16 \pm 0.09$ after 12 days, and $0.72 \pm 0.040 \mathrm{U} / \mathrm{g}_{\text {sf }}$ after 15 days of fermentation, respectively (Figure $4 \mathrm{C}$ ). No activity was observed on the non-inoculated substrate. Esterase and laccase production in SSF process seems to be associated with fungal growth phase, likely due to the very metabolic development of the microorganisms as previously reported [68-70].

Laccase, extracellular lipase and carboxylesterase are reported to be downregulated upon hypovirus infection [62]. In detail, the three laccase isoforms produced by C. parasitica [65] are modulated by the presence of hypovirus, and their activity is differentially suppressed by different CHV1 isolates, and also influenced by the culture conditions [66]. Surprisingly, in our study, $\mathrm{CpC} 4$ is the best laccase and esterase producer after 15 days of fermentation. The hypovirulent strain showed a level of activities 10-fold and 2-fold higher, respectively, than the other strains, in spite of being the only strain hosting CHV1. This apparently discordant behavior could be explained by the different genetic background of the pair Ep155 and its isogenic hypovirus infected strain, and the pair CpC4 and its virus free isogenic strain, producing quite different enzyme yields. In this regard, it would be interesting to cure $\mathrm{CpC} 4$ from the hypovirus to verify the $\mathrm{CHV} 1$ effect on the laccase production of the virus-free strain. Moreover, different hypoviruses and different CHV1 variants could cause a differential suppression of extracellular laccase, with some allowing a laccase activity to nearly virus-free levels [71]. Lastly, the culture conditions [71,72], such as the composition of the culture medium [72], could affect the enzymatic productions. Effectively, the different production of laccase and esterase found in the present study could be associated to specific features of the applied substrate and to the different timing used to assess the enzymes production compared to those applied in Rigling and Van Alfen [46], who found a 5-fold higher level of extracellular laccase expression by the dsRNA-free strain, grown in complete liquid medium for 5 days than the hypovirus infected isogenic strain.

The current finding of a hypovirulent strain characterized by an excellent enzymatic production makes the SSF method here presented a sustainable and completely circular technology. It offers the simultaneous production of multiple enzymes, and the possibility to use the SSF substrates entangled with the hypovirulent strain as fungal biomass to be applied in biological control treatment of chestnut cankers. The appreciable production of a cocktail of 3 enzymes (protease, lipase/esterase, and laccase) by single strains could be applied in textile industry [73].

As evidenced in this study, C. parasitica shows a high potential for its further study as an industrial enzyme-producing fungus. Several industries require cocktail of enzymes in place of a single enzyme, as the latter will not function as efficiently for many applications e.g., for biomass hydrolysis or detergents developments [74]. Development of a costeffective cocktail is still one of the major challenges. Hence single microorganisms able to produce multiple enzymes are needed as well as protocols for a concurrent production of multiple enzymes are of great value.

A summary of the protease, laccase and esterase activities from fungi is reported in Table 4. Although a direct comparison between data from the literature and our data is not possible due to the differences in the enzymatic assays used, protease and laccase production by $C$. parasitica registered higher yields than several values mentioned in the literature and, notably, without the need of any nutritional supplements. 
Table 4. Comparison of enzyme activity of protease, laccase and esterase/lipase from C. parasitica strains of current study with other reports.

\begin{tabular}{|c|c|c|c|c|c|c|c|}
\hline Enzyme & Microorganism & SSF Substrate & $\begin{array}{l}\text { Fermentation } \\
\text { Period }\end{array}$ & $\begin{array}{l}\text { Enzyme } \\
\text { Substate }\end{array}$ & Unit Definition & $\begin{array}{l}\text { Enzyme } \\
\text { Activity }\end{array}$ & Reference \\
\hline \multirow{3}{*}{ Protease } & $\begin{array}{c}\text { A. oryzae } \\
\text { MTCC } 5341\end{array}$ & $\begin{array}{l}\text { Wheat bran with } \\
\text { supplements }\end{array}$ & $120 \mathrm{~h}$ & Hemoglobin & $\begin{array}{l}1 \mathrm{U}=0.001 \text { increase } \\
\text { in } A_{280} \mathrm{~nm} / \mathrm{min}\end{array}$ & $\underset{\mathrm{a}}{864,000 \mathrm{U} / \mathrm{g}_{\mathrm{ds}}}$ & $\begin{array}{l}\text { Vishwanatha } \\
\text { et al., } 2010\end{array}$ \\
\hline & $\begin{array}{c}\text { C. parasitica } \\
\text { CpA }\end{array}$ & Wheat bran & 9 days & Hemoglobin & $\begin{array}{c}1 \mathrm{AU}=0.01 \\
\text { increase in } \\
\mathrm{A}_{280 \mathrm{~nm}} / \mathrm{min}\end{array}$ & $3955.6 \mathrm{U} / \mathrm{g}_{\mathrm{sf}} \mathrm{b}$ & $\begin{array}{l}\text { Current } \\
\text { study }\end{array}$ \\
\hline & $\begin{array}{l}\text { A. oryzae } \\
\text { (Ozykat-1) }\end{array}$ & $\begin{array}{l}\text { Wheat bran and } \\
\text { rice bran }\end{array}$ & 4 days & Casein & $\begin{array}{c}1 \mathrm{U}=\text { release } 1 \mu \mathrm{g} \\
\text { tyrosine } / \mathrm{min}\end{array}$ & $1200 \mathrm{U} / \mathrm{g}_{\mathrm{ds}}$ & $\begin{array}{l}\text { Chutmanop } \\
\text { et al., } 2008\end{array}$ \\
\hline \multirow{3}{*}{ Laccase } & $\begin{array}{l}\text { P. acaciicola } \\
\text { AGST3 }\end{array}$ & $\begin{array}{l}\text { Wheat bran with } \\
\text { supplements }\end{array}$ & 12 days & ABTS * & $\begin{array}{l}1 \mathrm{U}=\text { oxidation } 1 \\
\mu \mathrm{mol} \text { ABTS } / \mathrm{min}\end{array}$ & $535,000 \mathrm{U} / \mathrm{g}_{\mathrm{ds}}$ & $\begin{array}{l}\text { Thakur and } \\
\text { Gupte } 2015\end{array}$ \\
\hline & $\begin{array}{l}\text { T. versicolor } \\
\text { JSRK13 }\end{array}$ & $\begin{array}{c}\text { Parthenium sp. } \\
\text { with supplements }\end{array}$ & 17 days & Guaiacol & $\begin{array}{c}1 \mathrm{U}=0.01 \text { increase } \\
\mathrm{A}_{470 \mathrm{~nm}} / \mathrm{min}\end{array}$ & $185 \mathrm{U} / \mathrm{g}_{\mathrm{sf}}$ & $\begin{array}{l}\text { Singh et al., } \\
2019\end{array}$ \\
\hline & $\begin{array}{c}\text { C. parasitica } \\
\text { CpC4 }\end{array}$ & Wheat bran & 15 days & $\begin{array}{c}2,6- \\
\text { Dimethoxyphenol }\end{array}$ & $\begin{array}{c}1 \mathrm{AU}=1.0 \text { increase } \\
\mathrm{A}_{468} \mathrm{~nm} / \mathrm{min}\end{array}$ & $93.8 \mathrm{U} / \mathrm{g}_{\mathrm{sf}}$ & $\begin{array}{l}\text { Current } \\
\text { study }\end{array}$ \\
\hline \multirow{3}{*}{$\begin{array}{l}\text { Esterase } \\
\text { /Lipase }\end{array}$} & $\begin{array}{l}\text { R. microsporus } \\
\text { CPQBA } \\
\text { 312-07 DRM }\end{array}$ & $\begin{array}{l}\text { Wheat bran and } \\
\text { sugarcane bagasse } \\
\text { with supplements }\end{array}$ & $18 \mathrm{~h}$ & Olive oil & $\begin{array}{c}1 \mathrm{U}=\text { release } 1 \\
\mu \mathrm{mol} \text { fatty } \\
\mathrm{acid} / \mathrm{min}\end{array}$ & $265 \mathrm{U} / \mathrm{g}_{\mathrm{sf}}$ & $\begin{array}{l}\text { Pitol et al., } \\
\quad 2017\end{array}$ \\
\hline & $\begin{array}{l}\text { A. ibericus } \\
\text { MUM } 03.49\end{array}$ & $\begin{array}{l}\text { Olive pomace and } \\
\text { wheat bran with } \\
\text { supplements }\end{array}$ & 7 days & pNP-butyrate ${ }^{* *}$ & $\begin{array}{c}1 \mathrm{U}=\text { release } 1 \\
\mu \mathrm{mol} \text { di } \mathrm{pNP} / \mathrm{min}\end{array}$ & $223 \mathrm{U} / \mathrm{g}_{\mathrm{ds}}$ & $\begin{array}{l}\text { Oliveira } \\
\text { et al., } 2017\end{array}$ \\
\hline & $\begin{array}{c}\text { C. parasitica } \\
\text { CpC4 }\end{array}$ & Wheat bran & 15 days & pNP-butyrate & $\begin{array}{c}1 \mathrm{U}=\text { release } 1 \\
\mu \mathrm{mol} \text { di } \mathrm{pNP} / \mathrm{min}\end{array}$ & $2.55 \mathrm{U} / \mathrm{g}_{\mathrm{sf}}$ & $\begin{array}{l}\text { Current } \\
\text { study }\end{array}$ \\
\hline
\end{tabular}

Bold: Cryphonectria stain isolated in this work; ${ }^{a}{ }_{\mathrm{ds}}$ : dry substrate, ${ }^{\mathrm{b}}{ }_{\text {sf }}$ : substrate fermented; * ABTS: 2,2'-Azino-bis(3-ethylbenzothiazoline6-sulfonic acid); ** pNP-butyrate: p-Nitrophenyl butyrate.

According to the obtained results, further studies will be carried out to optimize the SSF protocol here presented. Parameters such as variation in $\mathrm{C} / \mathrm{N}$ ratio besides several other physicochemical factors are important in the development of fermentation process and their interactions should be evaluated in order to increase the expression of each enzyme of the cocktail to levels comparable to the best single producers.

\section{Conclusions}

The ability of the filamentous ascomycete C. parasitica to colonize agro-industrial wastes without any pre-treatment and supplements as a source of value-added bio-products by means of SSF was verified in this study.

To the best of our knowledge, this is the first report on multiple enzymes production by C. parasitica on agro-industrial wastes. All newly isolated C. parasitica strains were able to (i) grow, metabolize the substrate, and (ii) produce multiple enzymes on ZW without any other supplement. Interestingly, the crude extract obtained from the hypovirulent strain $\mathrm{CpC} 4$ showed the highest enzymatic activities, resulting an ideal candidate for further studies on the feasibility of large-scale production of industrially relevant enzymes.

In the circular economy view, the here presented approach could lead to develop a biorefinery without waste production. The fermentation substrates could be addressed for the production of microorganism-based fertilizer.

Supplementary Materials: The following are available online at https:/ / www.mdpi.com/article/10 .3390 / fermentation7040279/s1, Table S1. Total protein content of crude extract of four C. parasitica environmental strains ( $\mathrm{CpA}, \mathrm{CpB} 2, \mathrm{CpC} 4, \mathrm{CpC} 7)$, at different time points of fermentation, grown on $\mathrm{ZW}$ for 15 days. Data represent the average \pm standard deviation of biological replicate cultures $(n=3)$. Figure S1. Growth of CpC7 strain under SSF using as solid substrate spent coffee grounds (CGA and CGB) and rice husk (RHM and RHU). Cnt, not inoculated substrate (negative control). Figure S2. Preliminary evaluation of lipolytic activity by TBA assay. It showed that the zone of hydrolysis evidenced a transparent halo around the disks with fungal crude extracts starting at day 
6 (B), and increased with the age of the cultures day 9, 12, 15 (respectively, C, D, E); no transparent halo around in the samples corresponding to day 2 (A) and negative control not inoculated substrate (F).

Author Contributions: S.S.; Methodology, Investigation; Writing-original draft; D.B.; Investigation, Writing—review \& editing; E.M.; Resources, Validation, Supervision; E.G.; Conceptualization, Resources, Supervision, Writing-review \& editing. All authors have read and agreed to the published version of the manuscript.

Funding: This research did not receive any specific grant from funding agencies in the public, commercial, or not-for-profit sectors.

Institutional Review Board Statement: Not applicable.

Informed Consent Statement: Not applicable.

Conflicts of Interest: The authors declare no conflict of interest.

\section{References}

1. Bringezu, S.B.R. Sustainable Resource Management: Global Trends, Visions and Policies, 1st ed.; Taylor \& Francis: New York, NY, USA, 2009.

2. Ravindran, R.; Jaiswal, A.K. Exploitation of Food Industry Waste for High-Value Products. Trends Biotechnol. 2016, 34, 58-69. [CrossRef]

3. Belewu, M.A.; Babalola, F.T. Nutrient enrichment of waste agricultural residues after solid state fermentation using Rhizopus oligosporus. J. Appl. Biosci. 2009, 13, 695-699.

4. Sadh, P.K.; Duhan, S.; Duhan, J.S. Agro-industrial wastes and their utilization using solid state fermentation: A review. Bioresour. Bioprocess 2018, 5, 1. [CrossRef]

5. Singh, S.; Bajaj, B.K. Potential application spectrum of microbial proteases for clean and green industrial production. Energy Ecol. Environ. 2017, 2, 370-386. [CrossRef]

6. Marzo, C.; Díaz, A.B.; Caro, I.; Blandino, A. Valorization of agro-industrial wastes to produce hydrolytic enzymes by fungal solid-state fermentation. Waste Manag. Res. 2018, 37, 149-156. [CrossRef]

7. Alias, C.; Bulgari, D.; Bilo, F.; Borgese, L.; Gianoncelli, A.; Ribaudo, G.; Gobbi, E.; Alessandri, I. Food waste-assisted metal extraction from printed circuit boards: The aspergillus niger route. Microorganisms 2021, 9, 895. [CrossRef] [PubMed]

8. Razzaq, A.; Shamsi, S.; Ali, A.; Ali, Q.; Sajjad, M.; Malik, A.; Ashraf, M. Microbial Proteases Applications. Front. Bioeng. Biotechnol. 2019, 7, 110. [CrossRef] [PubMed]

9. Sarnthima, R.; Khammuang, S.; Svasti, J. Extracellular ligninolytic enzymes by Lentinus polychrous Lév. under solid-state fermentation of potential agro-industrial wastes and their effectiveness in decolorization of synthetic dyes. Biotechnol. Bioprocess Eng. 2009, 14, 513-522. [CrossRef]

10. Arregui, L.; Ayala, M.; Gómez-Gil, X.; Gutiérrez-Soto, G.; Hernández-Luna, C.E.; de los Santos, H.M.; Levin, L.; Rojo-Domínguez, A.; Romero-Martínez, D.; Saparrat, M.C.N.; et al. Laccases: Structure, function, and potential application in water bioremediation. Microb. Cell Fact. 2019, 18, 200. [CrossRef] [PubMed]

11. Barriuso, J.; Prieto, A.; Martínez, M.J. Fungal genomes mining to discover novel sterol esterases and lipases as catalysts. BMC Genom. 2013, 14, 712. [CrossRef]

12. Chandra, P.; Enespa; Singh, R.; Arora, P.K. Microbial lipases and their industrial applications: A comprehensive review. Microb. Cell Fact. 2020, 19, 169. [CrossRef]

13. Diaz, A.B.; Blandino, A.; Caro, I. Value added products from fermentation of sugars derived from agro-food residues. Trends Food Sci. Technol. 2018, 71, 52-64. [CrossRef]

14. Anitha, T.S.; Palanivelu, P. Purification and characterization of an extracellular keratinolytic protease from a new isolate of Aspergillus parasiticus. Protein Expr. Purif. 2013, 88, 214-220. [CrossRef]

15. Ramos, O.S.; Malcata, F.X. 3.48-Food-Grade Enzymes. In Comprehensive Biotechnology, 2nd ed.; Moo-Young, M., Ed.; Academic Press: Burlington, VT, USA, 2011; pp. 555-569. ISBN 978-0-08-088504-9.

16. Vandenberghe, L.P.S.; Pandey, A.; Carvalho, J.C.; Letti, L.A.J.; Woiciechowski, A.L.; Karp, S.G.; Thomaz-Soccol, V.; MartínezBurgos, W.J.; Penha, R.O.; Herrmann, L.W.; et al. Solid-state fermentation technology and innovation for the production of agricultural and animal feed bioproducts. Syst. Microbiol. Biomanuf. 2021, 1, 142-165. [CrossRef]

17. Soccol, C.R.; da Costa, E.S.F.; Letti, L.A.J.; Karp, S.G.; Woiciechowski, A.L.; de Souza, V.L.P. Recent developments and innovations in solid state fermentation. Biotechnol. Res. Innov. 2017, 1, 52-71. [CrossRef]

18. de Castro, R.J.S.; Sato, H.H. Enzyme Production by Solid State Fermentation: General Aspects and an Analysis of the Physicochemical Characteristics of Substrates for Agro-industrial Wastes Valorization. Waste Biomass Valorization 2015, 6, 1085-1093. [CrossRef]

19. Yazid, N.A.; Barrena, R.; Komilis, D.; Sánchez, A. Solid-state fermentation as a novel paradigm for organic waste valorization: A review. Sustainability 2017, 9, 224. [CrossRef] 
20. López-Gómez, J.P.; Venus, J. Potential role of sequential solid-state and submerged-liquid fermentations in a circular bioeconomy. Fermentation 2021, 7, 76. [CrossRef]

21. Webb, C. Design Aspects of Solid State Fermentation as Applied to Microbial Bioprocessing. J. Appl. Biotechnol. Bioeng. 2017, 4, 511-532. [CrossRef]

22. Carboué, Q.; Tranier, M.-S.; Perraud-Gaime, I.; Roussos, S. Production of Microbial Enzymes by Solid-state Fermentation for Food Applications. In Microbial Enzyme Technology in Food Applications; Ramesh, C., Ray, C.M.R., Eds.; CRC Press: London, UK; Taylor \& Francis Group Boca Raton: New York, NY, USA, 2017; ISBN 9781498749831.

23. Kumla, J.; Suwannarach, N.; Sujarit, K.; Penkhrue, W.; Kakumyan, P.; Jatuwong, K.; Vadthanarat, S.; Lumyong, S. Cultivation of Mushrooms and Their Lignocellulolytic Enzyme Production Through the Utilization of Agro-Industrial Waste. Molecules 2020, 25, 2811. [CrossRef]

24. Jatuwong, K.; Kumla, J.; Suwannarach, N.; Matsui, K.; Lumyong, S. Bioprocessing of Agricultural Residues as Substrates and Optimal Conditions for Phytase Production of Chestnut Mushroom, Pholiota adiposa, in Solid State Fermentation. J. Fungi 2020, 6, 384. [CrossRef]

25. Ramírez, C.M.G.; Rivera-Ríos, J.M.; Téllez-Jurado, A.; Maqueda Gálvez, A.P.; Mercado-Flores, Y.; Arana-Cuenca, A. Screening for thermotolerant ligninolytic fungi with laccase, lipase, and protease activity isolated in Mexico. J. Environ. Manage. 2012, 95, S256-S259. [CrossRef] [PubMed]

26. Sánchez, R.S.; Sánchez, G.I.; Arévalo-Villena, M.; Pérez, B.A. Production and immobilization of enzymes by solid-state fermentation of agroindustrial waste. Bioprocess Biosyst. Eng. 2015, 38, 587-593. [CrossRef] [PubMed]

27. Viayaraghavan, P.; Kumar, J.S.; Arasu, V.M.; Al-Dhabi, N.A. Simultaneous production of commercial enzymes using agro industrial residues by statistical approach. J. Sci. Food Agric. 2019, 99, 2685-2696. [CrossRef] [PubMed]

28. McCarroll, D.R.; Thor, E. Pectolytic, cellulytic and proteolytic activities expressed by cultures of Endothia parasitica, and inhibition of these activities by components extracted from Chinese and American chestnut inner bark. Physiol. Plant Pathol. 1985, 26, 367-378. [CrossRef]

29. Varley, D.A.; Podila, G.K.; Hiremath, S.T. Cutinase in Cryphonectria parasitica, the chestnut blight fungus: Suppression of cutinase gene expression in isogenic hypovirulent strains containing double-stranded RNAs. Mol. Cell. Biol. 1992, 12, $4539-4544$. [CrossRef] [PubMed]

30. Farias, G.M.; Gorbea, C.; Elkins, J.R.; Griffin, G.J. Purification, characterization, and substrate relationships of the tannase from Cryphonectria parasitica. Physiol. Mol. Plant Pathol. 1994, 44, 51-63. [CrossRef]

31. Chung, H.-J.; Kwon, B.-R.; Kim, J.-M.; Park, S.-M.; Park, J.-K.; Cha, B.-J.; Yang, M.-S.; Kim, D.-H. A tannic acid-inducible and hypoviral-regulated Laccase 3 contributes to the virulence of the chestnut blight fungus Cryphonectria parasitica. Mol. Plant. Microbe. Interact. 2008, 21, 1582-1590. [CrossRef] [PubMed]

32. FDA Microorganisms \& Microbial-Derived Ingredients Used in Food (Partial List). Available online: https://www.fda. gov / food/generally-recognized-safe-gras/microorganisms-microbial-derived-ingredients-used-food-partial-list (accessed on 20 November 2021).

33. Rigling, D.; Prospero, S. Cryphonectria parasitica, the causal agent of chestnut blight: Invasion history, population biology and disease control. Mol. Plant Pathol. 2018, 19, 7-20. [CrossRef]

34. Hillman, B.I.; Suzuki, N. Viruses of the chestnut blight fungus, Cryphonectria parasitica. Adv. Virus Res. 2004, 63, 423-472. [CrossRef]

35. Kazmierczak, P.; Pfeiffer, P.; Zhang, L.; Van Alfen, N.K. Transcriptional repression of specific host genes by the mycovirus Cryphonectria hypovirus 1. J. Virol. 1996, 70, 1137-1142. [CrossRef] [PubMed]

36. Wang, J.; Lu, L.; Yang, Y.; Chen, Q.; Chen, B. Proteomic analysis of Cryphonectria parasitica infected by a virulence-attenuating hypovirus. Wei Sheng Wu Xue Bao 2014, 54, 803-812. [PubMed]

37. Gobbi, E.; Rekab, D.; Locci, R. Mitochondrial plasmids of the pCp family are spread worldwide in Cryphonectria parasitica populations. Mycol. Res. 2002, 106, 1408-1416. [CrossRef]

38. Lione, G.; Giordano, L.; Turina, M.; Gonthier, P. Hail-Induced Infections of the Chestnut Blight Pathogen Cryphonectria parasitica Depend on Wound Size and May Lead to Severe Diebacks. Phytopathology 2020, 110, 1280-1293. [CrossRef]

39. Anson, M.L. The estimation of pepsin, trypsin, papain, and cathepsin with hemoglobin. J. Gen. Physiol. 1938, 22, 79-89. [CrossRef]

40. Tello-Solís, S.R.; Rodríguez-Romero, A.; Hernández-Arana, A. Circular dichroism studies of acid proteinases from Aspergillus niger and Aspergillus awamori. Biochem. Mol. Biol. Int. 1994, 33, 759-768.

41. Vishwanatha, K.S.; Rao, A.G.A.; Singh, S.A. Acid protease production by solid-state fermentation using Aspergillus oryzae MTCC 5341: Optimization of process parameters. J. Ind. Microbiol. Biotechnol. 2010, 37, 129-138. [CrossRef]

42. Meitner, P.A.; Kassell, B. Bovine pepsinogens and pepsins. A series of zymogens and enzymes that differ in organic phosphate content. Biochem. J. 1971, 121, 249-256. [CrossRef]

43. Stoops, J.K.; Horgan, D.J.; Runnegar, M.T.C.; De Jersey, J.; Webb, E.C.; Zerner, B. Carboxylesterases (EC 3.1.1). Kinetic studies on carboxylesterases. Biochemistry 1969, 8, 2026-2033. [CrossRef]

44. Kumar, D.; Kumar, L.; Nagar, S.; Raina, C.; Parshad, R.; Gupta, V.K. Screening, isolation and production of lipase/esterase producing Bacillus sp. strain DVL2 and its potential evaluation in esterification and resolution reactions. Arch. Appl. Sci. Res. 2012, 4, 1763-1770. 
45. Rigling, D.; Heiniger, U.; Hohl, H.R. Reduction of Laccase Activity in dsRNA-Containing Hypovirulent Strains of Cryphonectria (Endothia) Parasitica. Phytopathology 1989, 79, 219-2231. [CrossRef]

46. Rigling, D.; Van Alfen, N.K. Extra- and Intracellular Laccases of the Chestnut Blight Fungus, Cryphonectria parasitica. Appl. Environ. Microbiol. 1993, 59, 3634-3639. [CrossRef] [PubMed]

47. Bradford, M.M. A rapid and sensitive method for the quantitation of microgram quantities of protein utilizing the principle of protein-dye binding. Anal. Biochem. 1976, 72, 248-254. [CrossRef]

48. Whitaker, J.R. Protease of Endothia parasitica. In Proteolytic Enzymes; Methods in Enzymology; Academic Press: New York, NY, USA, 1970; Volume 19, pp. 436-445.

49. Gao, S.; Shain, L. Characterization of an endopolygalacturonase produced by the chestnut blight fungus. Physiol. Mol. Plant Pathol. 1994, 45, 169-179. [CrossRef]

50. Wu, B.; Gaskell, J.; Held, B.W.; Toapanta, C.; Vuong, T.V.; Ahrendt, S.; Lipzen, A.; Zhang, J.; Schilling, J.S.; Master, E.; et al. Retracted and Republished from: "Substrate-Specific Differential Gene Expression and RNA Editing in the Brown Rot Fungus Fomitopsis pinicola". Appl. Environ. Microbiol. 2021, 87, e00329-21. [CrossRef]

51. Shang, J.; Wu, X.; Lan, X.; Fan, Y.; Dong, H.; Deng, Y.; Nuss, D.L.; Chen, B. Large-scale expressed sequence tag analysis for the chestnut blight fungus Cryphonectria parasitica. Fungal Genet. Biol. 2008, 45, 319-327. [CrossRef]

52. Parker, M.L.; Ng, A.; Waldron, K.W. The phenolic acid and polysaccharide composition of cell walls of bran layers of mature wheat (Triticum aestivum L. cv. Avalon) grains. J. Sci. Food Agric. 2005, 85, 2539-2547. [CrossRef]

53. Cantero, D.A.; Martínez, C.; Bermejo, M.D.; Cocero, M.J. Simultaneous and selective recovery of cellulose and hemicellulose fractions from wheat bran by supercritical water hydrolysis. Green Chem. 2015, 17, 610-618. [CrossRef]

54. Pelizer, L.H.; de Moraes, I.O. Influence of water activity on chemical reactivity. Water Act. Theory Appl. Food 2017, 2, 27-54. [CrossRef]

55. Abbas, A.; Ansumali, S. Global Potential of Rice Husk as a Renewable Feedstock for Ethanol Biofuel Production. BioEnergy Res. 2010, 3, 328-334. [CrossRef]

56. Ballesteros, L.F.; Teixeira, J.A.; Mussatto, S.I. Chemical, Functional, and Structural Properties of Spent Coffee Grounds and Coffee Silverskin. Food Bioprocess Technol. 2014, 7, 3493-3503. [CrossRef]

57. Chutmanop, J.; Chuichulcherm, S.; Chisti, Y.; Srinophakun, P. Protease production by Aspergillus oryzae in solid-state fermentation using agroindustrial substrates. J. Chem. Technol. Biotechnol. 2008, 83, 1012-1018. [CrossRef]

58. Rodríguez Couto, S. Exploitation of biological wastes for the production of value-added products under solid-state fermentation conditions. Biotechnol. J. 2008, 3, 859-870. [CrossRef]

59. Macchione, M.M.; Merheb, C.W.; Gomes, E.; da Silva, R. Protease Production by Different Thermophilic Fungi. Appl. Biochem. Biotechnol. 2008, 146, 223-230. [CrossRef] [PubMed]

60. Basheer, S.M.; Chellappan, S.; Beena, P.S.; Sukumaran, R.K.; Elyas, K.K.; Chandrasekaran, M. Lipase from marine Aspergillus awamori BTMFW032: Production, partial purification and application in oil effluent treatment. N. Biotechnol. 2011, 28, 627-638. [CrossRef] [PubMed]

61. Thakur, S.; Gupte, A. Optimization and hyper production of laccase from novel agaricomycete Pseudolagarobasidium acaciicola AGST3 and its application in in vitro decolorization of dyes. Ann. Microbiol. 2015, 65, 185-196. [CrossRef]

62. Pitol, L.O.; Finkler, A.T.J.; Dias, G.S.; Machado, A.S.; Zanin, G.M.; Mitchell, D.A.; Krieger, N. Optimization studies to develop a low-cost medium for production of the lipases of Rhizopus microsporus by solid-state fermentation and scale-up of the process to a pilot packed-bed bioreactor. Process. Biochem. 2017, 62, 37-47. [CrossRef]

63. Wang, J.; Shi, L.; He, X.; Lu, L.; Li, X.; Chen, B. Comparative Secretome Analysis Reveals Perturbation of Host Secretion Pathways by a Hypovirus. Sci. Rep. 2016, 6, 34308. [CrossRef]

64. Van Alfen, N.K.; Jaynes, R.A.; Anagnostakis, S.L.; Day, P.R. Chestnut Blight: Biological Control by Transmissible Hypovirulence in Endothia parasitica. Science 1975, 12, 890-891. [CrossRef]

65. Shapira, R.; Choi, G.H.; Nuss, D.L. Virus-like genetic organization and expression strategy for a double-stranded RNA genetic element associated with biological control of chestnut blight. EMBO J. 1991, 10, 731-739. [CrossRef]

66. Allen, T.D.; Dawe, A.L.; Nuss, D.L. Use of cDNA Microarrays To Monitor Transcriptional Responses of the Chestnut Blight Fungus Cryphonectria parasitica to Infection by Virulence-Attenuating Hypoviruses. Eukaryot. Cell 2003, 2, 1253-1265. [CrossRef]

67. Ikasari, L.; Mitchell, D.A. Protease production by Rhizopus oligosporus in solid-state fermentation. World J. Microbiol. Biotechnol. 1994, 10, 320-324. [CrossRef]

68. Rivera-Hoyos, C.; Morales-Álvarez, E.; Poutou-Piñales, R.; Pedroza-Rodríguez, A.; Vazquez, R.R.; Delgado-Boada, J. Fungal Laccases. Fungal Biol. Rev. 2013, 27, 67-82. [CrossRef]

69. Majeau, J.-A.; Brar, S.K.; Tyagi, R.D. Laccases for removal of recalcitrant and emerging pollutants. Bioresour. Technol. 2010, 101, 2331-2350. [CrossRef] [PubMed]

70. Masutti, D.; Borgognone, A.; Setti, L. Production of Enzymes from Rice Husks and Wheat Straw in Solid State Fermentation. Chem. Eng. Trans. 2012, 27, 133-138. [CrossRef]

71. Parsley, T.B.; Chen, B.; Geletka, L.M.; Nuss, D.L. Differential Modulation of Cellular Signaling Pathways by Mild and Severe Hypovirus Strains. Eukaryot. Cell 2002, 1, 401-413. [CrossRef]

72. Geisseler, D.; Horwath, W.R. Regulation of extracellular protease activity in soil in response to different sources and concentrations of nitrogen and carbon. Soil Biol. Biochem. 2008, 40, 3040-3048. [CrossRef] 
73. Tzanov, T.; Basto, C.; Gübitz, G.M.; Cavaco-Paulo, A. Laccases to Improve the Whiteness in a Conventional Bleaching of Cotton. Macromol. Mater. Eng. 2003, 288, 807-810. [CrossRef]

74. Naganthran, A.; Masomian, M.; Rahman, R.N.Z.R.A.; Ali, M.S.M.; Nooh, H.M. Improving the Efficiency of New Automatic Dishwashing Detergent Formulation by Addition of Thermostable Lipase, Protease and Amylase. Molecules 2017, $22,1577$. [CrossRef] 